\title{
Inhibition Studies of the Synergistic Effect of Rosemary oil and Zinc oxide on S41003 Ferritic Steel Corrosion in Dilute Sulphuric and Hydrochloric Acid Solutions
}

\author{
ROLAND TOLULOPE LOTO \\ Department of Mechanical Engineering, Covenant University, Ota, Ogun State, Nigeria. \\ Corresponding author E-mail: tolu.loto@gmail.com \\ http://dx.doi.org/10.13005/ojc/340127
}

(Received: November 03, 2017; Accepted: December 05, 2017)

\begin{abstract}
Corrosion inhibition studies of the synergistic properties of the combined admixture of Rosemary oil and zinc oxide (ROZ) on $\mathrm{S} 41003$ ferritic steel in $1 \mathrm{M} \mathrm{HCl}$ and $\mathrm{H}_{2} \mathrm{SO}_{4}$ acid were done with potentiodynamic polarization, weight loss analysis, open circuit potential measurement, optical microscopy and ATR-FTIR spectroscopy. Results showed the admixed compound to be highly effective with maximum inhibition efficiencies of $93.68 \%$ and $93.26 \%, 98.93 \%$ and $90.5 \%$ in $\mathrm{HCl}$ and $\mathrm{H}_{2} \mathrm{SO}_{4}$ acid solutions from the electrochemical tests with dominant cathodic type inhibition characteristics. ROZ addition significantly shifts the corrosion potential values of $\mathrm{S} 41003$ to cathodic potentials from open circuit potential evaluation in both acid media signifying specific corrosion inhibition behavior without applied potential. Identified functional groups of alcohols, phenols, $1^{\circ}, 2^{\circ}$ amines, amides, carbonyls (general), esters, saturated aliphatic, carboxylic acids, ethers, aliphatic amines, alkenes, aromatics, alkyl halides and alkynes within ROZ compound aggregated completely on $\mathrm{S} 41003$ steel surface in $\mathrm{HCl}$ and partially in $\mathrm{H}_{2} \mathrm{SO}_{4}$ solution. Thermodynamic calculations showed physisorption molecular interaction and adsorption according to Langmuir and Frumkin isotherm models. Optical microscopy images of ROZ inhibited and uninhibited S41003 samples slightly differ from each other due to pre-adsorbed corrosive anions on the steel surface before ROZ inhibition.
\end{abstract}

Keywords: Corrosion, Inhibitor, Steel, Acid, Adsorption.

\section{INTRODUCTION}

Stainless steels have a wide variety of industrial applications. They are corrosion resistant in specific environments due to the formation of a thin protective film on their surface. Deterioration of these films results in localized corrosion reactions responsible for corrosion failures such as pitting, intergranular, hydrogen embrittlement corrosion etc. in aqueous environments containing sufficient amounts of chlorides and sulphates anions. The ability of the protective film to reform on the steel

This is an $\mathbf{C}$ Open Access article licensed under a Creative Commons Attribution-NonCommercial-ShareAlike 4.0 International License (https://creativecommons.org/licenses/by-nc-sa/4.0/ ), which permits unrestricted NonCommercial use, distribution and reproduction in any medium, provided the original work is properly cited. 
surface after deterioration determines their resistance against localized failures. Chlorides and sulphates containing solutions are widely used in various technological processes in industry such as in pickling baths, mineral extraction and processing, oil and gas refinery, and chemical and petrochemical processing industries. In some cases they appear as a result of hydrolysis of salts which is catastrophic to equipment made of steel. Corrosion problem within these industries is a major problem as it represents a significant portion of loss due to lost production, high cost of maintenance and corrosion control ${ }^{1}$. Chemical compounds known as inhibitors are commonly used to reduce the corrosion attack on metallic materials ${ }^{2,3}$. Application of corrosion inhibitors has been widely studied to solve metallic corrosion problems ${ }^{4,5}$. Chemical compounds of natural and organic origin are the most promising for metallic corrosion inhibition due to their environmentally safe properties. The inhibition efficiency of these compounds is strongly dependent on the structure and chemical properties of the layer formed on the metal surface. Physiochemical properties of the compounds such as functional groups, steric factors, aromaticity, and their electronic structure influence their performance. In view of the toxic effect of most chemical inhibitors, this research aims to study the synergistic effect of rosemary oil and zinc oxide on $\mathrm{S} 41003$ stainless steel in dilute $\mathrm{HCl}$ and $\mathrm{H}_{2} \mathrm{SO}_{4}$ acid media.

\section{MATERIALS AND METHODS}

\section{Materials and preparation}

S41003 stainless steel (S41003) has a nominal composition (wt $\%$ ) of $0.03 \% \mathrm{C}, 1.5 \% \mathrm{Mn}$, $1 \% \mathrm{Si}, 0.04 \% \mathrm{P}, 0.015 \% \mathrm{~S}, 13 \% \mathrm{Cr}, 1 \% \mathrm{Ni}, 0.03 \%$ $\mathrm{N}$ and Fe (balance). The steel has a cylindrical shape with dimensions of $1.8 \mathrm{~cm}$ diameter and 1 $\mathrm{cm}$ length. Steel specimens were machined and abraded with silicon carbide papers $(80,320,600$, 800 and 1000 grits) before washing with distilled water and acetone, and kept in a desiccator for potentiodynamic polarization and weight loss measurement test according to ASTM G1 $-03^{6}$. Rosemary oil obtained from NOW Foods, USA is a golden, translucent, oily liquid with major compositions such as p-cymene $(44.02 \%)$, linalool $(20.5 \%)$, gamma-terpinene $(16.62 \%)$, thymol
(1.81\%), beta-pinene $(3.61 \%)$, alphapinene $(2.83 \%)$ and eucalyptol (2.64\%). It is also composed of monoterpenic hydrocarbons, oxygenated monoterpenes and sesquiterpene hydrocarbons ${ }^{7}$. It has a molar mass (active groups) of $691.14 \mathrm{~g} / \mathrm{mol}$. Zinc oxide obtained from the University of Lagos, Nigeria, has a molar mass of $81.38 \mathrm{~g} / \mathrm{mol}$. It is a greyish white powder, insoluble in water and is widely used as an additive in numerous materials and products. The combined admixture of the compounds (ROZ) was prepared in molar concentrations of $6.47 \times 10^{3}, 1.29 \times 10^{2}, 1.94 \times 10^{2}$, $2.59 \times 10^{2}, 3.24 \times 10^{2} 3.88 \times 10^{2}$ in $200 \mathrm{~mL}$ of $1 \mathrm{M} \mathrm{HCl}$ and $\mathrm{H}_{2} \mathrm{SO}_{4}$ solutions, prepared from analar grade of both acids $\left(37 \% \mathrm{HCl}\right.$ and $\left.98 \% \mathrm{H}_{2} \mathrm{SO}_{4}\right)$ with distilled water.

\section{Potentiodynamic polarization test}

Polarization measurements were carried out at $30 \% \mathrm{C}$ ambient temperature with a three electrode system, conical glass cell containing 200 $\mathrm{mL}$ of the acid test solution and Digi-Ivy 2311 potentiostat. $\$ 41003$ steels embedded in resin mounts with an unconcealed surface area of 2.54 $\mathrm{cm}^{2}$ were prepared according to ASTM G59-978. Potentiodynamic polarization curves were produced at a scan rate of $0.0015 \mathrm{~V} / \mathrm{s}$ between potentials of $-1 \mathrm{~V}$ and $+1.5 \mathrm{~V}$ according to ASTM G102-89. Platinum rod was used as the counter electrode and silver chloride electrode $(\mathrm{Ag} / \mathrm{AgCl})$ as the reference electrode. Corrosion current density $\left(J_{c r}, A / \mathrm{cm}^{2}\right)$ and corrosion potential $\left(E_{c r}, V\right)$ values were obtained using the Tafel extrapolation method whereby the estimated corrosion current, $I_{c r}$, was obtained from the intercept of the two linear segment of the Tafel slope of the cathodic and anodic polarization plots ${ }^{10,11}$. The corrosion rate $\left(C_{\mathrm{R}}\right)$ was calculated from the mathematical relationship

$C_{\mathrm{R}}=\frac{0.00327 J_{\mathrm{cr}} E_{\mathrm{qv}}}{d}$

where $E_{\mathrm{qv}}$ is the sample equivalent weight in grams, 0.00327 is a constant for corrosion rate calculation $(\mathrm{mm} / \mathrm{y})^{12}$ and $D$ is the density $\left(\mathrm{g} / \mathrm{cm}^{3}\right)$ The inhibition efficiency $(\eta$, \%) was calculated from the corrosion rate values according to equation 2

$\eta=1-\left[\frac{C_{\mathrm{R} 2}}{C_{\mathrm{R} 1}}\right] * 100$ 
$C_{\mathrm{R} 1}$ and $C_{\mathrm{R} 2}$ are the corrosion rates of the uninhibited and inhibited steel specimens. Polarization resistance $\left(R_{\mathrm{p}}, \Omega\right)$ was calculated from equation 3 below

$R_{\mathrm{p}}=2.303 \frac{B_{\mathrm{a}} B_{\mathrm{c}}}{B_{\mathrm{a}}+B_{\mathrm{c}}}\left(\frac{1}{I_{\mathrm{cr}}}\right)$

Where $B_{a}$ is the anodic Tafel slope and $B_{c}$ is the cathodic Tafel slope, both are measured as (V/dec).

\section{FTIR spectroscopy and optical microscopy characterization}

$\mathrm{ROZ} / 1 \mathrm{M} \mathrm{HCl}$ and $\mathrm{H}_{2} \mathrm{SO}_{4}$ solution (before and after the corrosion test) was exposed to specific range of infrared ray beams from Bruker Alpha FTIR spectrometer at wavelength range of 375 to 7500 $\mathrm{cm}^{-1}$ and resolution of $0.9 \mathrm{~cm}^{-1}$. The transmittance and reflectance of the infrared beams at various frequencies were decoded and transformed into an ATR-FTIR absorption plot consisting of spectra peaks. The spectral pattern was evaluated and equated with the theoretical ATR-FTIR absorption table to identify the functional groups responsible for corrosion inhibition. Micro-analytical images of the corroded and inhibited S41003 steel surface morphology from optical microscopy were analysed after the electrochemical test with Omax trinocular with the aid of ToupCam analytical software.

\section{Weight loss and open circuit potential measurement}

Measured S41003 coupons separately immersed in $200 \mathrm{~mL}$ of the dilute acid test solution for $240 \mathrm{~h}$ at $30{ }^{\circ} \mathrm{C}$ were weighed at $24 \mathrm{~h}$ interval according to ASTM G31-72 ${ }^{13}$. Corrosion rate $\left(C_{\mathrm{R}}\right)$ was determined as follows as ${ }^{14}$

$$
C_{\mathrm{R}}=\left[\frac{87.6 \omega}{D A t}\right]
$$

$\omega$ is the weight loss (mg), $D$ is the density in $\mathrm{g} / \mathrm{cm}^{3}, A$ is the total surface area of the coupon incm $^{2}$ and 87.6 is a constant for corrosion rate determination. $t$ is the time in $\mathrm{h}$. Inhibition efficiency (h) was determined from the mathematical relationship

$$
\eta=\left[\frac{\omega_{1}-\omega_{2}}{\omega_{1}}\right]
$$

$$
\theta=\left[1-\frac{\omega_{2}}{\omega_{1}}\right]
$$

$\omega_{1}$ and $\omega_{2}$ are the weight loss at specific ROZ concentrations. Surface coverage was determined from the relationship ${ }^{15,16}$

where $\theta$ is the degree of ROZ compound, adsorbed per gram of the steel samples. $\omega_{1}$ and $\omega_{2}$ are the weight loss of each steel coupon at specific concentrations of ROZ in the acid solution. OCP measurements were obtained at a step potential of $0.05 \mathrm{~V} / \mathrm{s}$ with two-electrode electrochemical cell consisting of $\mathrm{Ag} / \mathrm{AgCl}$ reference electrode and resin mounted steel specimens (exposed surface of 2.54 $\mathrm{cm}^{2}$ ) as the working electrode, connected to DigiIvy 2311 potentiostat according to ASTM G69-12 17 . The electrodes were fully immersed in $200 \mathrm{ml}$ of the test media at specific concentrations of ROZ for 2400s

\section{RESULTS AND DISCUSSION}

\section{Potentiodynamic polarization studies}

The potentiodynamic polarization plots for S41003 in $1 \mathrm{M} \mathrm{HCl}$ and $\mathrm{H}_{2} \mathrm{SO}_{4}$ solutions are shown in Figs. 1 and 2. Experimental results are presented in Table 1. The corrosion rate values of the inhibited S41003 samples $(0.5 \%-2.5 \%$ ROZ) in both acids significantly contrasts the values obtained for S41003 specimen at $0 \% \mathrm{ROZ}$ due to the inhibiting action of ROZ compound on S41003. The observed differences in corrosion rate coincide with decrease in corrosion current density and increase in polarization resistance values with increase in $\mathrm{ROZ}$ concentration. ROZ maintained effective inhibition efficiency values with optimal inhibition efficiency of $93.68 \%$ (2.5\% ROZ) and $94.49 \%$ (1.5\% ROZ) in $\mathrm{HCl}$ and $\mathrm{H}_{2} \mathrm{SO}_{4}$ solution. The corrosion rate results for $\mathrm{S} 41003$ in $\mathrm{HCl}$ are significantly lower than values in $\mathrm{H}_{2} \mathrm{SO}_{4}$ due to the ability of $\mathrm{H}_{2} \mathrm{SO}_{4}$ to completely ionize in solution releasing two protons that strongly react with the steel surface compared to $\mathrm{HCl}$ which releases one proton. This also explains the comparatively similar inhibition efficiencies of $\mathrm{ROZ}$ in both acids as $\mathrm{ROZ}$ protonates strongly in $\mathrm{H}_{2} \mathrm{SO}_{4}$ allowing more molecules to release electrons, this phenomenon increases the reactivity of ROZ compound enabling strong interaction with the steel surface $^{18}$. 
ROZ shifts the polarization plots of $\mathrm{S} 41003$ in $\mathrm{HCl}$ to cathodic potentials with respect to its concentration due to suppression of electron flow across the metal-solution interface. The higher the concentration of ROZ, the greater the cathodic shift. This phenomenon is responsible for the low anodic Tafel slope values in comparison to values for cathodic Tafel slope (Table 1), as a result ion transfer processes of anodic reaction are also restricted. ROZ probably adsorbed selectively on cathodic areas to limit the diffusion of reducing species, increasing the surface impedance of the alloy. In $\mathrm{H}_{2} \mathrm{SO}_{4}$ solution, there is a large cathodic shift of the polarization plot at $0.5 \%$ and $2.5 \% \mathrm{ROZ}$ i.e. at the highest and lowest concentration studied. The cathodic shift at $1 \%-2 \% \mathrm{ROZ}$ is limited, however the cathodic inhibition property of ROZ is clearly visible. The cathodic inhibition property of ROZ occurred due to electrostatic attractive forces between the ionic charges or dipoles on the adsorbed ROZ molecule and the electric charge on S41003 at the metal-solution interface.
The functional groups and structure of $\mathrm{ROZ}$ binds to the metal surface by electron transfer to form a coordinate type of linkage responsible for the strong bonding and effective inhibition. The zinc component of $\mathrm{ROZ}$ compound reacts with the products of the cathodic reaction $\left(\mathrm{OH}^{\prime \prime}\right)$ to form insoluble $\mathrm{Zn}(\mathrm{OH})_{2}$ which precipitates at cathodic sites on S41003 surfaces as the local environment becomes more alkaline due to the reduction reaction at these sites ${ }^{19-21}$. Zinc particles enhance the inhibition performance of $\mathrm{ROZ}$ through formation of a barrier between the acid solution and the alloy surface. Zinc being more electrochemically active than iron, serves as the anode for the steel in the acid solution preventing the formation of small anodic and cathodic sites on the metal surface. The anodic Tafel slope values obtained signifies the presence of surface oxides from the slow electron transfer step which remained generally the same due to minimal variation in electrode substrate, rate controlling step and influence of potential controlled



Fig. 1. Potentiodynamic polarization curves for $\mathrm{S} 41003$ in $1 \mathrm{M} \mathrm{HCl}(0 \%-2.5 \% \mathrm{ROZ})$

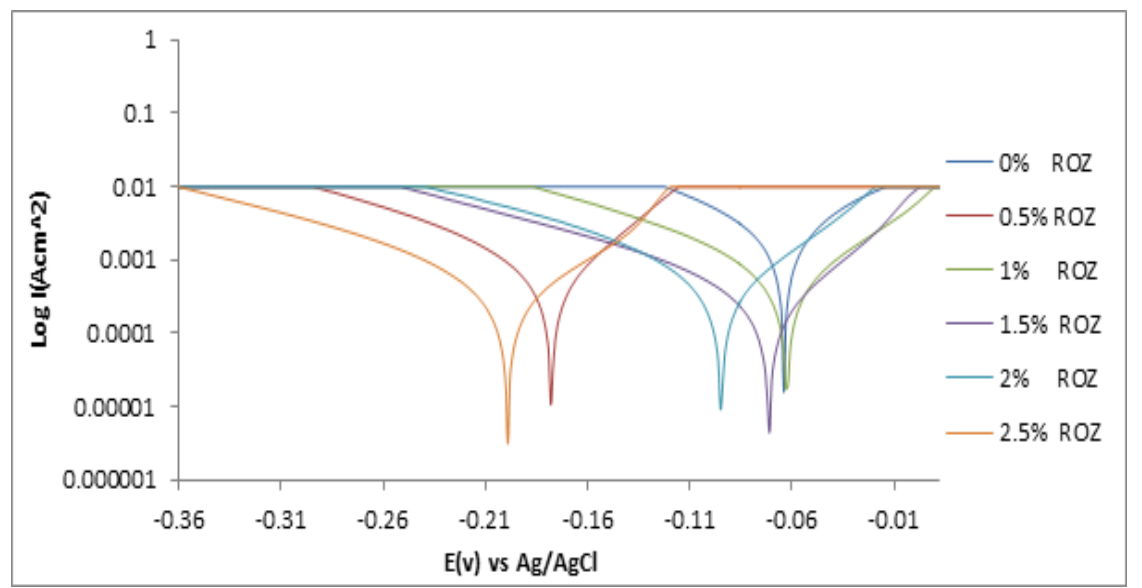

Fig. 2. Potentiodynamic polarization curves for $\mathrm{S} 41003$ in $1 \mathrm{M} \mathrm{H}_{2} \mathrm{SO}_{4}(0 \%-2.5 \% \mathrm{ROZ})$ 


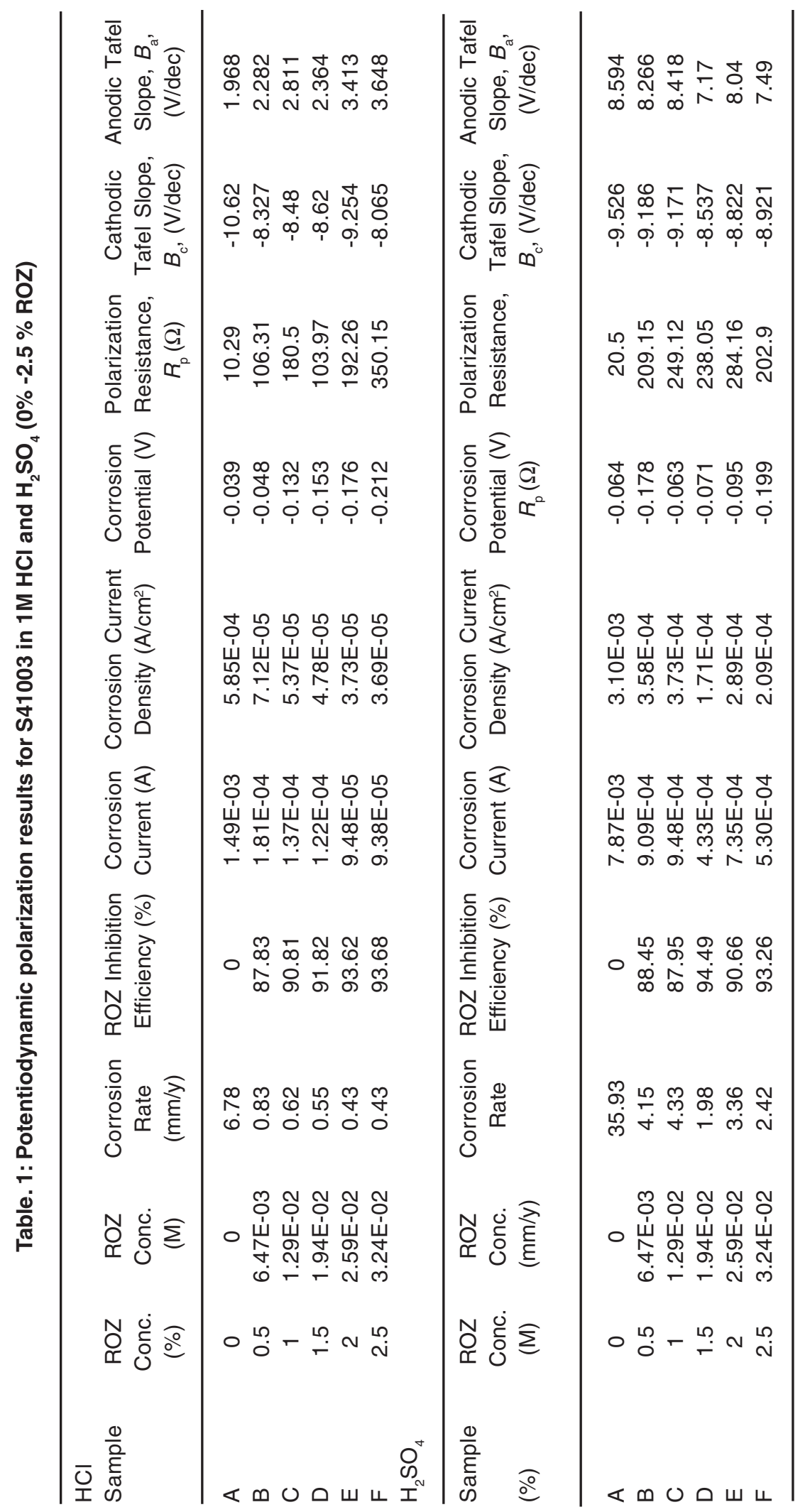


conditions $^{22,23}$. The maximum change in corrosion potential value in $\mathrm{HCl}$ and $\mathrm{H}_{2} \mathrm{SO}_{4}$ solution $173 \mathrm{mV}$ and $135 \mathrm{mV}$ in the cathodic direction, thus ROZ is a cathodic inhibitor.

\section{Adsorption Isotherm}

The inhibition efficiency of a corrosion inhibiting compounds is majorly a product of its adsorption strength on the alloy surface. The surface protection of ROZ depends upon the orientation of adsorption of the inhibitor molecule on the metal surface, and also the ionization and polarization of ROZ molecules ${ }^{24}$. Adsorption isotherms give valuable information about the molecular interaction between the adsorbed inhibitor molecules and the valence electrons of the alloy surface. The adsorption mechanism occurs when liquid solute aggregates on metallic surfaces, forming a molecular or atomic film. The mechanism of ROZ inhibition on S41003 was studied through adsorption isotherms models which show the phenomenon governing the retention of a substance from aqueous solution to solid interphase at a constant temperature and $\mathrm{pH}^{25,26}$. Langmuir and Frumkin gave the best fitting for $\mathrm{ROZ}$ adsorption in $\mathrm{HCl}$ and $\mathrm{H}_{2} \mathrm{SO}_{4}$ as shown from Figs. 3(a) - 4(b) according to equations (7-9).

$$
\theta=\left[\frac{K_{\mathrm{ROZ}} C_{\mathrm{ROZ}}}{1+K_{\mathrm{ads}} C_{\mathrm{ROZ}}}\right]
$$

Graphical plots of vs $C_{\mathrm{ROz}}$ aligns with the Langmuir isotherm [Fig. 3(a) and 3(b)], with a

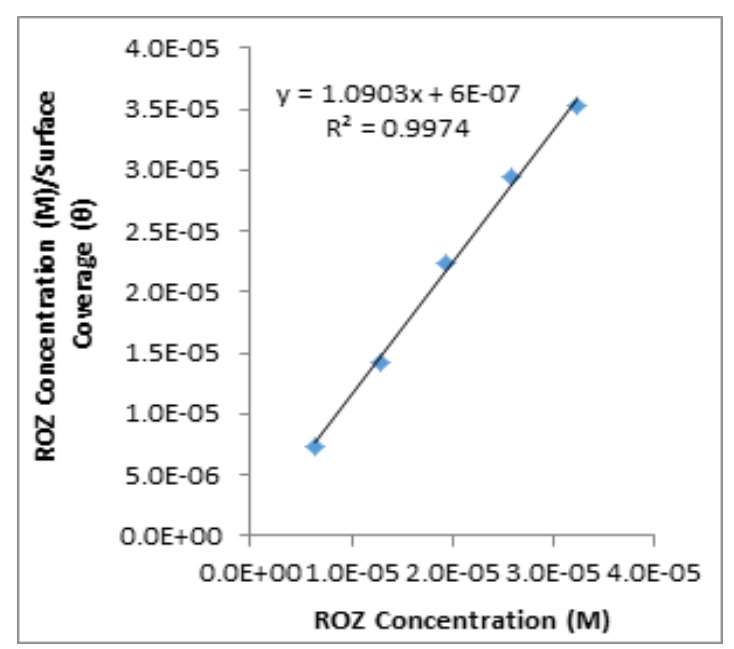

(a) $C_{\mathrm{ROZ}}$ correlation coefficient of 0.9974 in $\mathrm{HCl}$ solution and 0.9981 in $\mathrm{H}_{2} \mathrm{SO}_{4}$ according to the Langmuir equation below.

$\theta$ is the degree of ROZ adsorbed per unit weight on $\mathrm{S} 41003$ surface at equilibrium. $C_{\mathrm{ROZ}}$ is $\mathrm{ROZ}$ concentration and $K_{\mathrm{ROz}}$ is the equilibrium constant of adsorption. Langmuir isotherm assumes monomolecular layer adsorption at specific reaction areas on the alloy surface. The molecular adsorptions are similar, proportionate and no lateral interaction between the adsorbed molecules exists $^{27}$.

The Frumkin adsorption isotherm assumes heterogeneous nature of the steel surface i.e. the effect of lateral interaction apparent according to the equation below ${ }^{28}$;

$\theta / 1-\theta=K_{\mathrm{ROZ}} C_{\mathrm{ROZ}} e^{2 \alpha \theta}$

rearranging the equation becomes

$\log \left[\theta /(1-\theta) C_{\mathrm{ROZ}}\right]=\log K_{\mathrm{ROZ}}+2 \alpha \theta$

$\alpha$ is the interaction parameter which describes the molecular interaction in adsorbed layer, and calculated from the slope of the Frumkin isotherm plot. Taking into account, the attraction $(\alpha>0)$, repulsion $(\alpha<0)$ and no interaction $(\alpha=0)$ between the adsorbed species, the isotherm becomes equivalent to the Langmuir isotherm. For

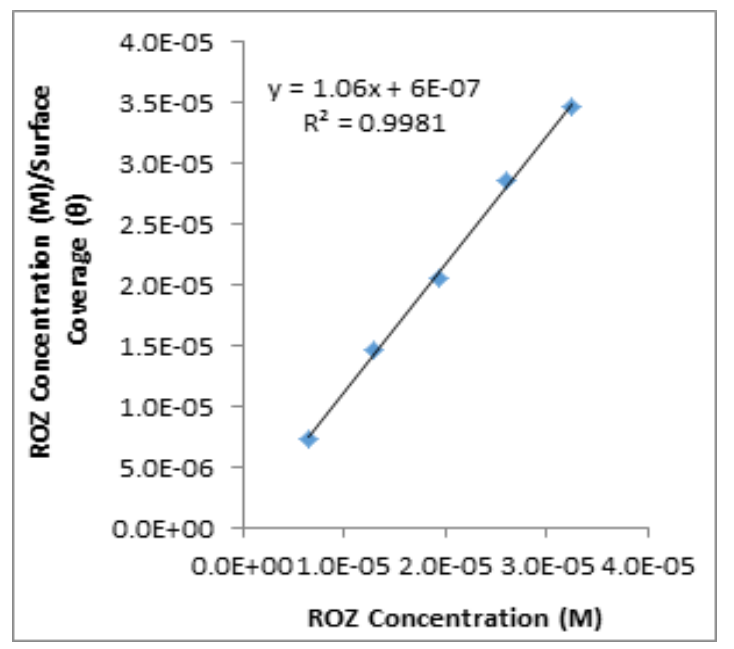

(b)

Fig. 3: Langmuir plot of $\frac{C_{\mathrm{ROZ}}}{\theta}$ versus $\mathrm{ROZ}$ concentration (a) in $1 \mathrm{M} \mathrm{HCl}$, (b) in $1 \mathrm{M} \mathrm{H}_{2} \mathrm{SO}_{4}$ 
+ve $\alpha$, adsorption energy increases with $\theta$ whereas for negative $\alpha$ adsorption energy decreases with $\theta$. $K_{\mathrm{ROZ}}$ is the equilibrium constant of adsorption. Plots of log versus $\theta$ in Fig. 4(a) and (b) showed a correlation coefficient of 0.8614 in $\mathrm{HCl}$ and 0.8135 in $\mathrm{H}_{2} \mathrm{SO}_{4}$.

\section{Thermodynamics of the corrosion inhibition}

The adsorption strength and nature of inhibition mechanism of ROZ on $\$ 41003$ was determined from the thermodynamics of ROZ molecular interaction with the alloy surface through the equilibrium constant of adsorption from the Langmuir Isotherm due to its correlation coefficient being cloeser unity. Calculated results of Gibbs free energy of adsorption in $\mathrm{HCl}$ and $\mathrm{H}_{2} \mathrm{SO}_{4}$ solution is shown in Table 2, from the following equation ${ }^{29}$.

$$
\Delta G_{\mathrm{ads}}-2.303 R T \log \left[55.5 K_{\mathrm{Roz}}\right]
$$

55.5 is the molar concentration of water in the acid solution, $R$ is the universal gas constant, $T$ is the absolute temperature and $K_{\mathrm{ROz}}$ is the equilibrium constant of adsorption. Negative values of $\Delta G^{\circ}$ ads signify spontaneous and stable adsorption reactions. In $\mathrm{HCl}$ solution, the lowest $\Delta G^{\circ}$ ads value is $-25.13 \mathrm{kJmol}^{-1}$ at $3.24 \times 10^{2} \mathrm{M}$ and the highest $\Delta G^{\circ}$ ads value of $-27.34 \mathrm{kJmol}^{-1}$ at $6.47 \times 10^{3} \mathrm{M}$ on $\mathrm{S} 41003$ surface. The lowest and highest values in $\mathrm{H}_{2} \mathrm{SO}_{4}$ are $-24.96 \mathrm{kJmol}^{-1}$ at $3.24 \times 10^{2} \mathrm{M}$ and $-27.51 \mathrm{kJmol}^{-}$

${ }^{1}$ at $6.47 \times 10^{3} \mathrm{M}$. These $\Delta G^{o}$ ads values in both acid

Table. 2: Results for Gibbs free energy $\left(\Delta G^{\circ}{ }_{\text {ads }}\right)$, surface coverage $(\theta)$ and equilibrium constant of adsorption $\left(K_{\mathrm{ROZ}}\right)$ for $\mathrm{ROZ}$ adsorption on $\mathrm{S} 41003$ in $1 \mathrm{M} \mathrm{HCl}$ and $\mathrm{H}_{2} \mathrm{SO}_{4}$ acid solution

$\mathrm{HCl}$

\begin{tabular}{lcccc} 
Sample & $\begin{array}{c}\mathrm{ROZ} \\
\text { Concentration } \\
(\mathrm{M})\end{array}$ & $\begin{array}{c}\text { Surface } \\
\text { Coverage } \\
(\theta)\end{array}$ & $\begin{array}{c}\text { Equilibrium Constant } \\
\text { of adsorption }\left(K_{\mathrm{ROZ}}\right)\end{array}$ & $\begin{array}{c}\text { Gibbs Free Energy, } \\
\text { "G }\left(\mathrm{kJmol}^{-1}\right)\end{array}$ \\
\hline $\mathrm{A}$ & 0 & 0 & 0 & 0 \\
$\mathrm{~B}$ & $6.47 \mathrm{E}-03$ & 0.878 & 1115.2 & -27.34 \\
$\mathrm{C}$ & $1.29 \mathrm{E}-02$ & 0.908 & 766.0 & -26.41 \\
$\mathrm{D}$ & $1.94 \mathrm{E}-02$ & 0.918 & 578.6 & -25.71 \\
$\mathrm{E}$ & $2.59 \mathrm{E}-02$ & 0.936 & 566.6 & -25.66 \\
$\mathrm{~F}$ & $3.24 \mathrm{E}-02$ & 0.937 & 457.8 & -25.13 \\
$\mathrm{H}_{2} \mathrm{SO}_{4}$ & & & &
\end{tabular}

\begin{tabular}{lcccc}
\hline Sample & $\mathrm{ROZ}$ & Surface & Equilibrium Constant \\
Concentration & Coverage & of adsorption $\left(K_{\mathrm{ROZ}}\right)$ & $\begin{array}{c}\text { Gibbs Free Energy, } \\
\text { " } G\left(\mathrm{Jmol}{ }^{-1}\right)\end{array}$
\end{tabular}

(M)

$(\theta)$

$\begin{array}{ccccc}\text { A } & 0 & 0 & 0 & 0 \\ \text { B } & 6.47 \mathrm{E}-03 & 0.885 & 1183.8 & -27.49 \\ \text { C } & 1.29 \mathrm{E}-02 & 0.88 & 566 & -25.66 \\ \text { D } & 1.94 \mathrm{E}-02 & 0.945 & 884.6 & -26.77 \\ \text { E } & 2.59 \mathrm{E}-02 & 0.907 & 374.6 & -24.64 \\ \text { F } & 3.24 \mathrm{E}-02 & 0.933 & 427.3 & -24.96\end{array}$

media depict physisorption adsorption reaction mechanisms i.e. physical interaction of ROZ molecules through van der waals forces on the steel's surface ${ }^{30,}{ }^{31}$. The result also proves that the inhibition mode is through surface coverage of the steel surface in accordance to Langmuir and Frumkin adsorption isotherm.

\section{ATR-FTIR spectroscopy analysis}

Molecular functional groups responsible for the characteristic chemical reactions of corrosion inhibition of S41003 steel within ROZ compound and the bond type within their molecular structure in $\mathrm{HCl}$ and $\mathrm{H}_{2} \mathrm{SO}_{4}$ solution was identified by ATFFTIR spectroscopy as shown on Tables 3 and 4 
after being matched with the ATR-FTIR Theoretical Table $^{32,33}$. The spectra curves of the acid test solution before and after corrosion from both acids are shown in Fig. 5. The calculated wave numbers of identified functional groups of alcohols, phenols, $1^{\circ}, 2^{\circ}$ amines, amides, carbonyls (general), esters, saturated aliphatic, carboxylic acids, ethers, aliphatic amines, alkenes, aromatics, alkyl halides and alkynes within $\mathrm{ROZ}$ molecules in $\mathrm{HCl}$ solution (Table 3) before corrosion (without S41003 steel) slightly increased to higher wave numbers after corrosion (in the presence of S41003). This show the functional groups aggregated on the steel surface did not chemisorb, confirming the inhibition mode to be through surface coverage as a result of molecular attraction by van der waals forces whereby the diffusion of corrosive anions onto the steel are effectively hindered. The observation

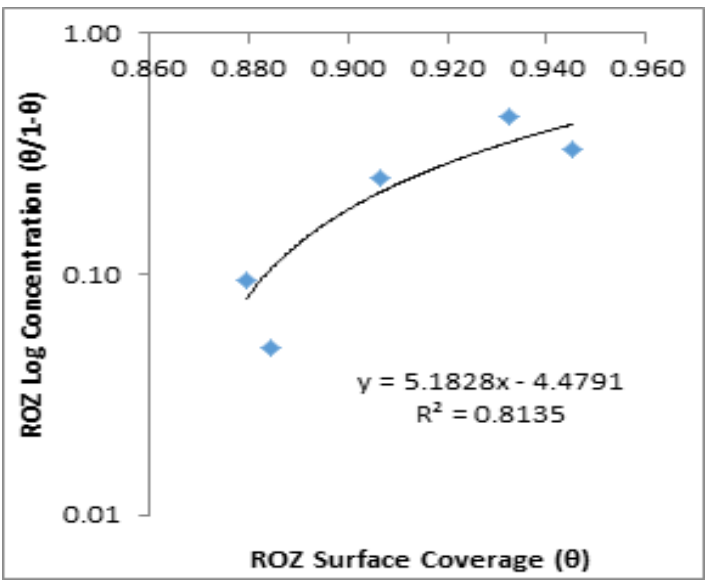

(a) agrees with result from thermodynamics of corrosion inhibition. The bonds within their molecular structure of the earlier mentioned functional groups consists of $\mathrm{O}-\mathrm{H}$ stretch, $\mathrm{H}-$ bonded, $\mathrm{N}-\mathrm{H}$ stretch, $\mathrm{C}=\mathrm{O}$ stretch, $\mathrm{C}-\mathrm{O}$ stretch, $\mathrm{C}-\mathrm{H}$ wag $\left(-\mathrm{CH}_{2} \mathrm{X}\right), \mathrm{C}-\mathrm{N}$ stretch, $=\mathrm{C}-\mathrm{H}$ bend, $\mathrm{N}-\mathrm{H}$ wag, $\mathrm{C}-\mathrm{H}$ "oop", $\mathrm{C}-\mathrm{Cl}$ stretch, $\mathrm{C}-\mathrm{Cl}$ stretch, $-\mathrm{Ca} \equiv \mathrm{C}-\mathrm{H}, \mathrm{C}-\mathrm{H}$ bend and $\mathrm{C}-\mathrm{Br}$ stretch which are responsible for attachment to the valence electron of S41003 steel.

The observation for $\mathrm{ROZ}$ adsorption and inhibition in $\mathrm{H}_{2} \mathrm{SO}_{4}$ solution contrast the earlier observation in $\mathrm{HCl}$ solution. Functional groups of carboxylic acids, alkanes, carbonyls (general), esters, saturated aliphatic, alcohols, ethers, alkyl halides, aliphatic amines, alkenes, $1^{\circ}, 2^{\circ}$ amines, aromatics and alkyl halides consisting of specific

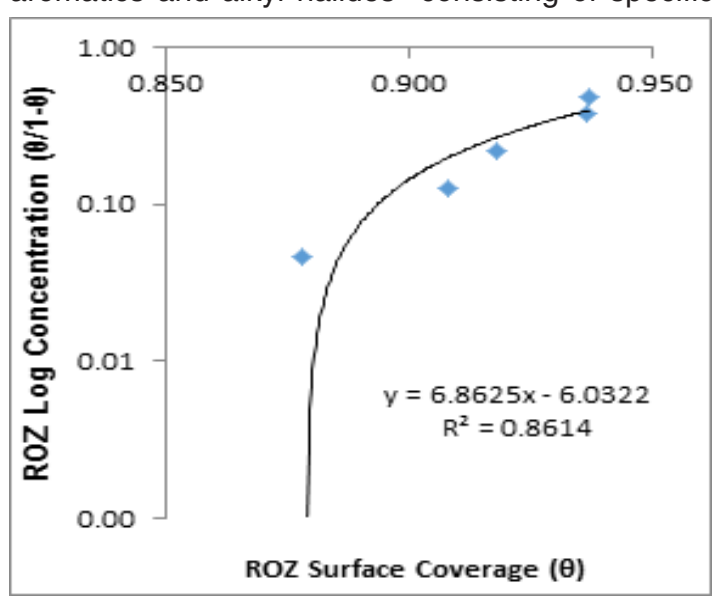

(b)

Fig. 4. Frumkin isotherm plot of $\log [\theta /(1-\theta) c]$ versus $\theta$ (a) in (a) $1 \mathrm{M} \mathrm{HCl}$, (b) $1 \mathrm{M} \mathrm{H}_{2} \mathrm{SO}_{4}$

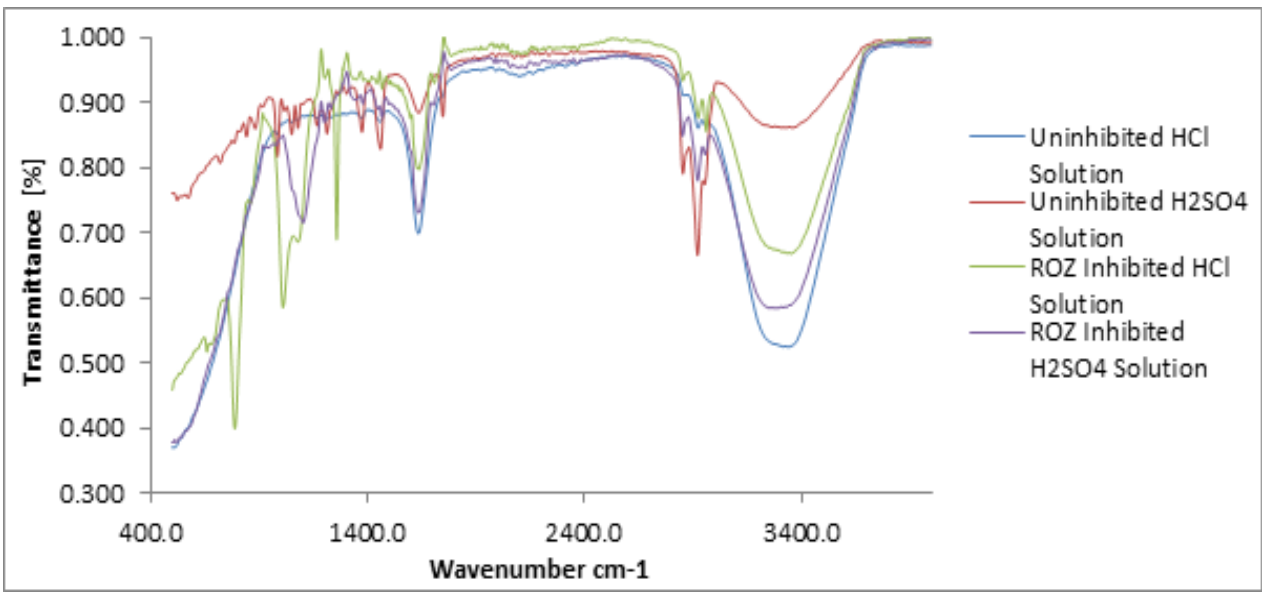

Fig. 5. ATF-FTIR spectra of $\mathrm{ROZ}$ compound in $1 \mathrm{M} \mathrm{HCl}$ and $\mathrm{H}_{2} \mathrm{SO}_{4}$ solution before and after S41003 corrosion 


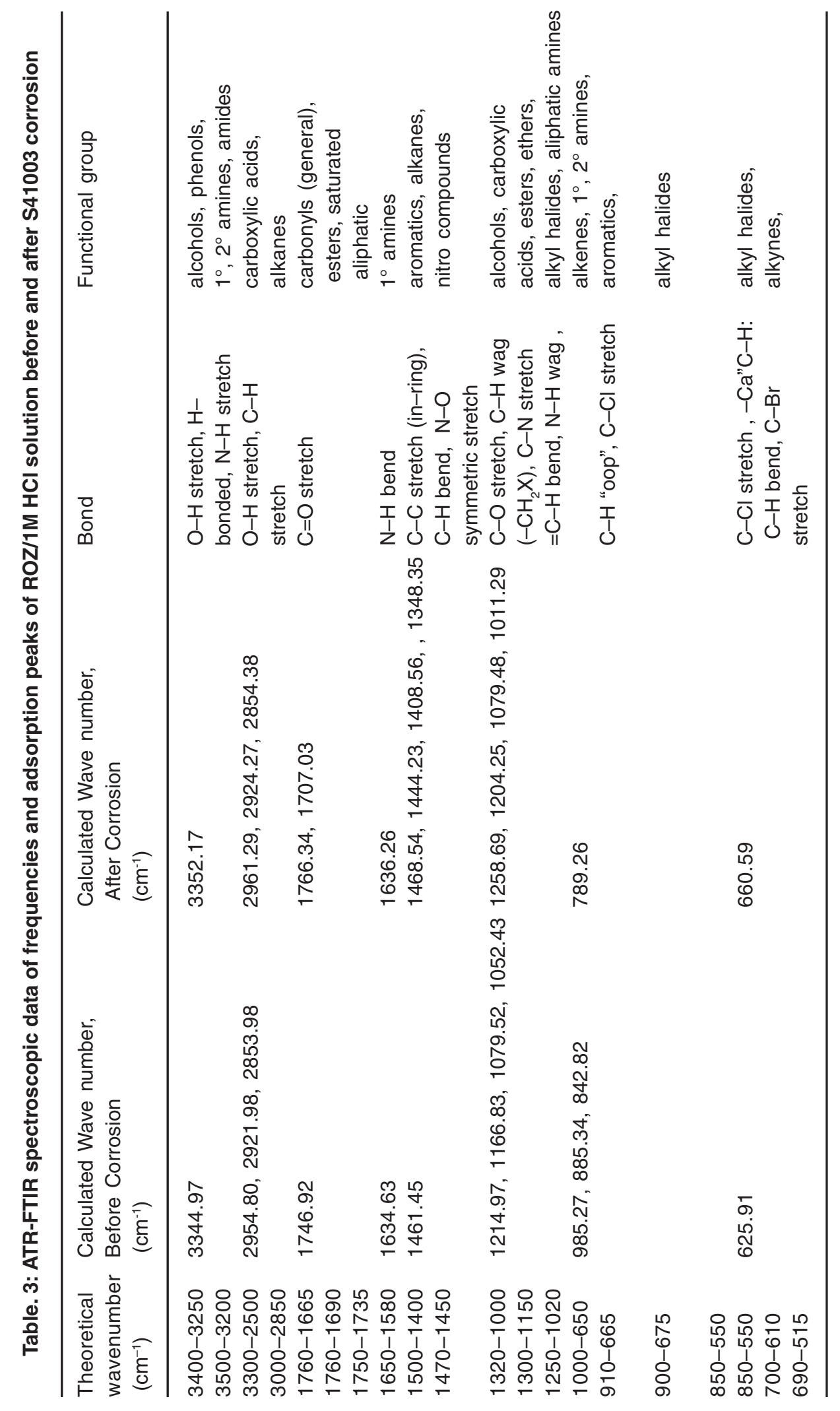




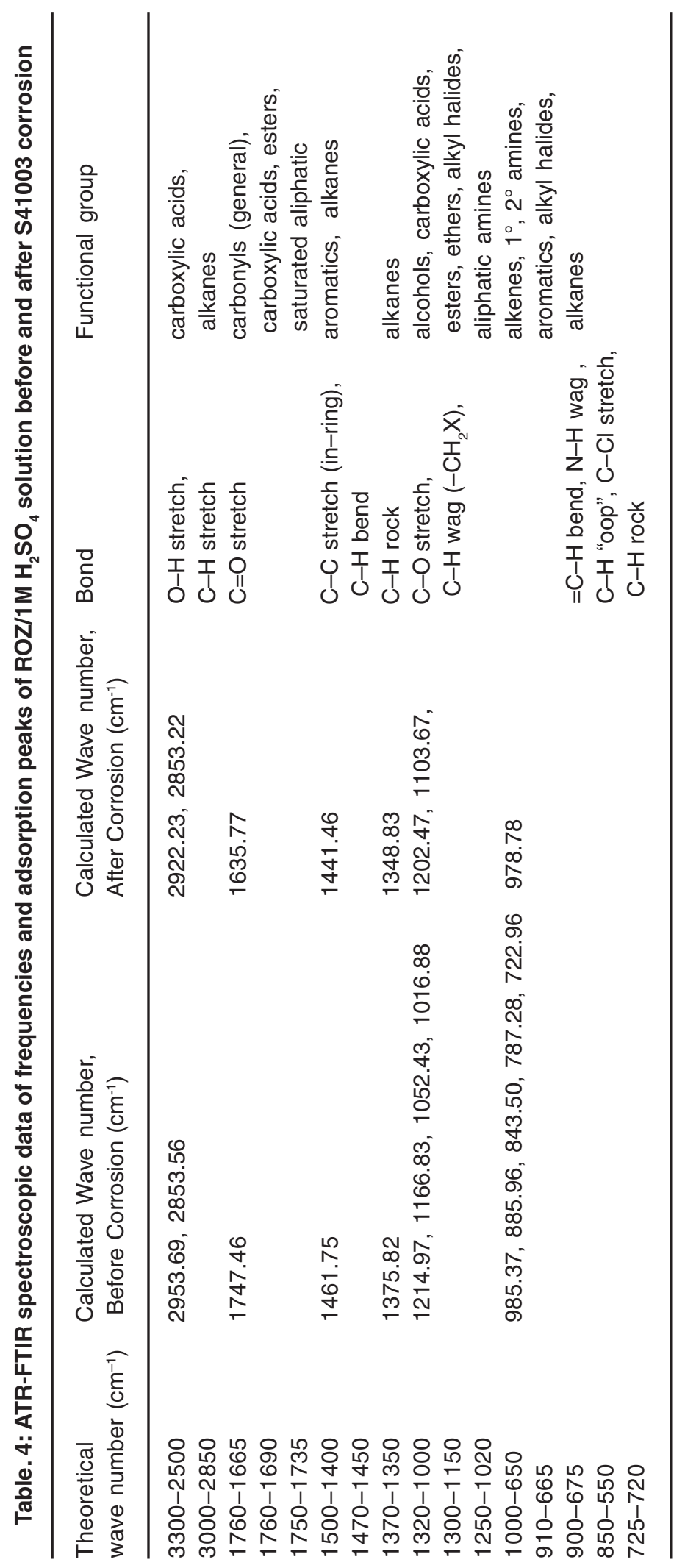


bond types (Table 4) significantly adsorbed onto S41003 steel. The calculated wavelengths values after corrosion (with $\mathrm{S} 41003$ steel) shows the functional groups in $\mathrm{H}_{2} \mathrm{SO}_{4}$ solution partially adsorbed onto the steel while simultaneously forming a protective covering on the steel.

Weight loss and open circuit potential (OCP) measurements

Plots of corrosion rate versus exposure time for $\$ 41003$ from weight loss measurement are shown in Fig. 6(a) and 6(b). Data from for $\$ 41003$ corrosion rate $\left(C_{\mathrm{R}}\right)$, weight loss $(\omega)$ and $\mathrm{ROZ}$ inhibition efficiency $(\eta)$ at $240 \mathrm{~h}$ are shown in Table 5. Fig. 7 shows the OCP measurement of uninhibited and ROZ inhibited $\mathrm{S} 41003$ samples in both acid media. The corrosion rate of $\mathrm{S} 41003$ at $0 \% \mathrm{ROZ}$ in $\mathrm{HCl}$ increased progressively till $0.0219 \mathrm{~mm} / \mathrm{y}$ at $240 \mathrm{~h}$, compared to the alloy's behavior in $\mathrm{H}_{2} \mathrm{SO}_{4}$ solution where with its corrosion rate value decreased suddenly after $48 \mathrm{~h}$ of exposure and remained generally constant until $216 \mathrm{~h}$, thereafter it slightly decreased further to

Table. 5: Result for $\mathrm{S} 41003$ inhibition in $1 \mathrm{M} \mathrm{HCl}$ and $\mathrm{H}_{2} \mathrm{SO}_{4} 240 \mathrm{~h}$ from weight loss measurement

\begin{tabular}{lccccc}
\hline $\begin{array}{l}\mathrm{HCl} \\
\text { Samples }\end{array}$ & $\begin{array}{c}\text { Weight } \\
\text { Loss (g) }\end{array}$ & $\begin{array}{c}\text { ROZ } \\
\text { Concentration (\%) }\end{array}$ & $\begin{array}{c}\text { ROZ } \\
\text { Concentration (M) }\end{array}$ & $\begin{array}{c}\text { Corrosion } \\
\text { Rate (mm/yr) }\end{array}$ & $\begin{array}{c}\text { ROZ Inhibition } \\
\text { Efficiency (\%) }\end{array}$ \\
\hline $\mathrm{A}$ & 4.196 & 0 & 0 & 0.0219 & 0 \\
$\mathrm{~B}$ & 0.376 & 0.5 & $6.47 \mathrm{E}-03$ & 0.0021 & 91.04 \\
$\mathrm{C}$ & 0.316 & 1 & $1.29 \mathrm{E}-02$ & 0.0020 & 92.46 \\
$\mathrm{D}$ & 0.404 & 1.5 & $1.94 \mathrm{E}-02$ & 0.0022 & 90.36 \\
$\mathrm{E}$ & 0.399 & 2 & $2.59 \mathrm{E}-02$ & 0.0022 & 90.50 \\
$\mathrm{~F}$ & 0.045 & 2.5 & $3.24 \mathrm{E}-02$ & 0.0003 & 98.92 \\
$\mathrm{H}_{2} \mathrm{SO}_{4}$ & & & & & \\
\hline Samples & Weight & $\mathrm{ROZ}$ & $\mathrm{ROZ}$ & Corrosion & ROZ Inhibition \\
& Loss (g) & Concentration (\%) & Concentration (M) & Rate (mm/yr) & Efficiency (\%) \\
\hline $\mathrm{A}$ & 9.5395 & 0 & 0 & 0.0568 & 0 \\
$\mathrm{~B}$ & 1.5045 & 0.5 & $6.47 \mathrm{E}-03$ & 0.0066 & 84.23 \\
$\mathrm{C}$ & 1.4208 & 1 & $1.29 \mathrm{E}-02$ & 0.0070 & 85.11 \\
$\mathrm{D}$ & 0.9012 & 1.5 & $1.94 \mathrm{E}-02$ & 0.0047 & 90.55 \\
$\mathrm{E}$ & 1.2019 & 2 & $2.59 \mathrm{E}-02$ & 0.0062 & 87.40 \\
$\mathrm{~F}$ & 0.9058 & 2.5 & $3.24 \mathrm{E}-02$ & 0.0054 & 90.50 \\
\hline
\end{tabular}

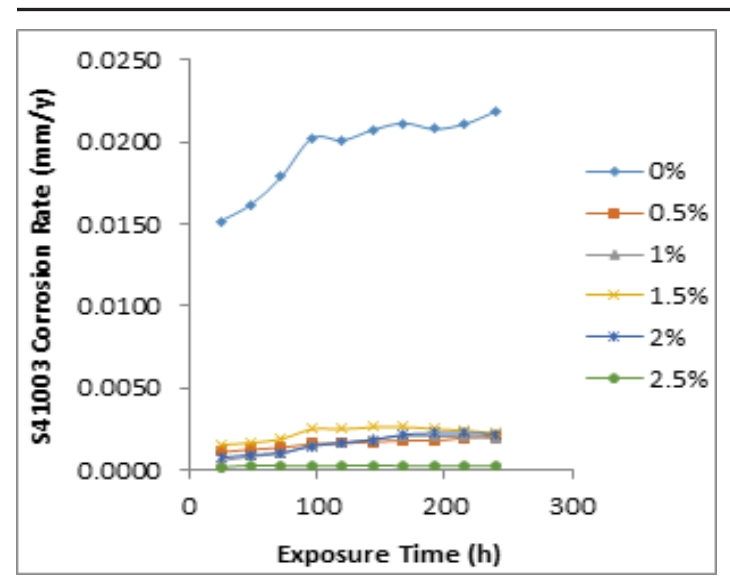

(a)

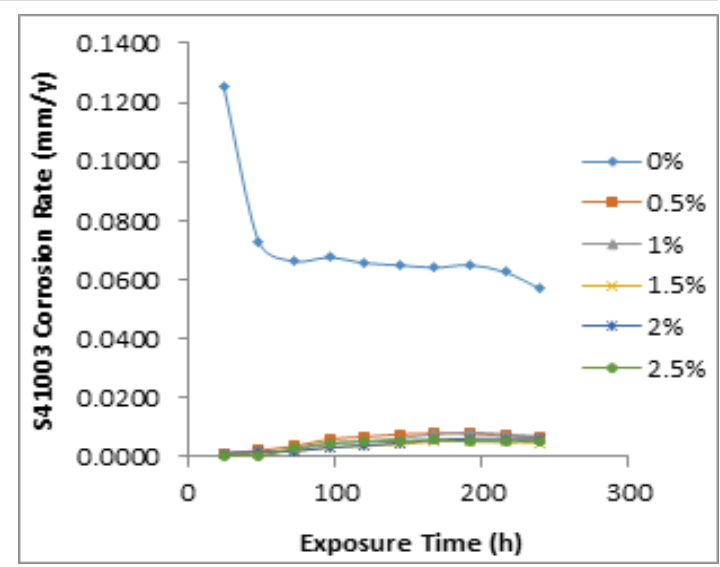

(b)

Fig. 6: Plot of $\mathrm{S} 41003$ corrosion rate versus exposure time at $0 \%-2.5 \% \mathrm{ROZ}$ concentration (a) in $1 \mathrm{M} \mathrm{HCl}$, (b) in $1 \mathrm{M} \mathrm{H}_{2} \mathrm{SO}_{4}$ 


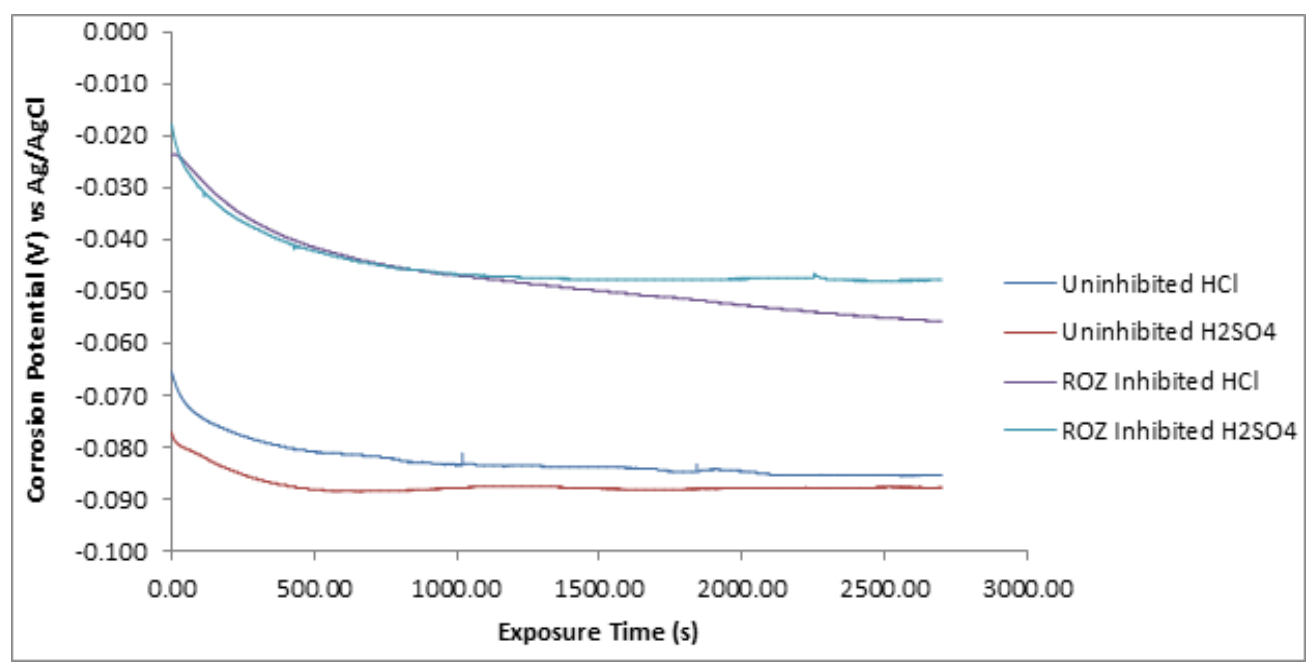

Fig. 7. Variation of corrosion potential with exposure time for $\$ 41003$ samples immersed in $1 \mathrm{M}$ $\mathrm{HCl}$ and $\mathrm{H}_{2} \mathrm{SO}_{4}$ acid solutions

$0.0568 \mathrm{~mm} / \mathrm{y}$ at $240 \mathrm{~h}$. Addition of ROZ compound changed the electrochemical nature and mechanism of reaction of the acid test solutions. The corrosion rate of S41003 decreased sharply after $0 \% \mathrm{ROZ}$ in both acids, showing similar trend in corrosion rate values at $0.5 \%-2.5 \% \mathrm{ROZ}$ with respect to exposure time due to the effective inhibiting action of $\mathrm{ROZ}$ compound. This observation is consistent with the OCP plot of potential vs time (Fig. 7). In the absence of ROZ compound $\mathrm{S} 41003$ had an OCP value of $-0.066 \mathrm{~V}$ in $\mathrm{HCl}$; this value decreased to $-0.083 \mathrm{~V}$ at $876 \mathrm{~s}$ and remained generally constant till 2700s. In $\mathrm{H}_{2} \mathrm{SO}_{4}$, the OCP value of $\mathrm{S} 41003$ started at $-0.077 \mathrm{~V}$ at 0 s and decreased to $-0.088 \mathrm{~V}$ at $515 \mathrm{~s}$ after which it remained generally constant till 2700 s, signifying the dominant effect of the cathodic reaction mechanism during $\mathrm{S} 41003$ corrosion. Addition of ROZ compound significantly altered the active passive behavior of $\mathrm{S} 41003$ with a major shift in corrosion potential values to $-0.024 \mathrm{~V}$ and $-0.018 \mathrm{~V}$ in $\mathrm{HCl}$ and $\mathrm{H}_{2} \mathrm{SO}_{4}$ solution. These values decreased to $-0.047 \mathrm{~V}$ at $1076 \mathrm{~s}$ for both acids. The potential value of $\mathrm{S} 41003$ in $\mathrm{HCl}$ continued to decrease until $-0.056 \mathrm{~V}$ at 2700 s while the value in $\mathrm{H}_{2} \mathrm{SO}_{4}$ remained generally constant henceforth till 2700s. The corrosion rate plots in Figs. 6(a) and (b) shows ROZ efficiency is independent of concentration with the exception of $2.5 \% \mathrm{ROZ}$ in $\mathrm{HCl}$ which attains a maximum inhibition of $98.92 \%$. ROZ stifled the

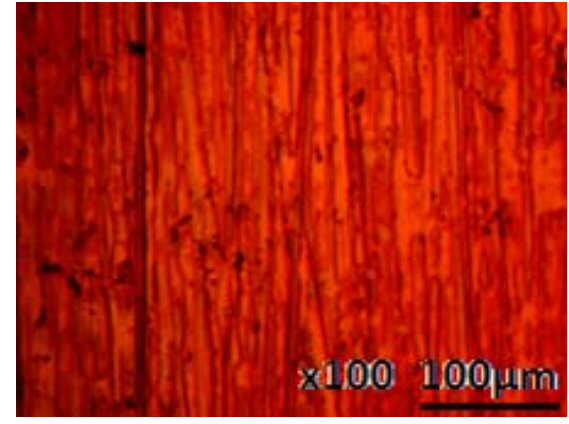

Fig. 8. Optical microscopy image of untested S41003 sample

hydrogen evolution and oxygen reduction reactions

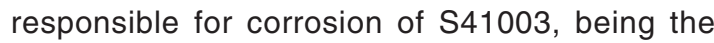
dominant reaction mechanism from potentiodynamic polarization study. The release of metal cations into the acid solutions through the action of $\mathrm{Cl}^{-}$and $\mathrm{SO}_{4}{ }^{2-}$ ions was effectively inhibited through surface coverage and modification of the corrosive test solution.

\section{Optical microscopy analysis}

Optical microscopy images of $\mathrm{S} 41003$ before and after corrosion test with and without $\mathrm{ROZ}$ compound from $\mathrm{HCl}$ and $\mathrm{H}_{2} \mathrm{SO}_{4}$ solution are shown from Figs. 8 to 10(b). Fig. 8 shows the optical image of S41003 steel before corrosion at mag. $x 100$, the result of machining and metallography. The optical image of S41003 samples [Figs. 9(a) and 10(a)] from $\mathrm{HCl}$ and $\mathrm{H}_{2} \mathrm{SO}_{4}$ solution shows a severely 
degraded morphology due to the action of chloride and sulphate anions. The two morphologies without $\mathrm{ROZ}$ compounds tend to be generally similar in surface deterioration as a result of the formation of numerous micro-pits after the destruction of the passive protective film resulting from severe active corrosion reactions of anodic dissolution. In the presence of ROZ the dynamics of the electrochemical corrosion mechanism changes resulting in the surface morphology shown in Fig.

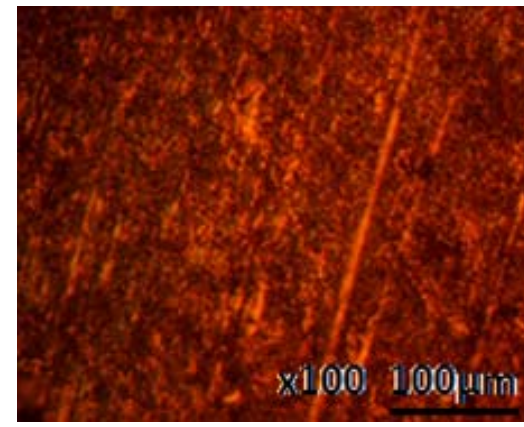

(a)

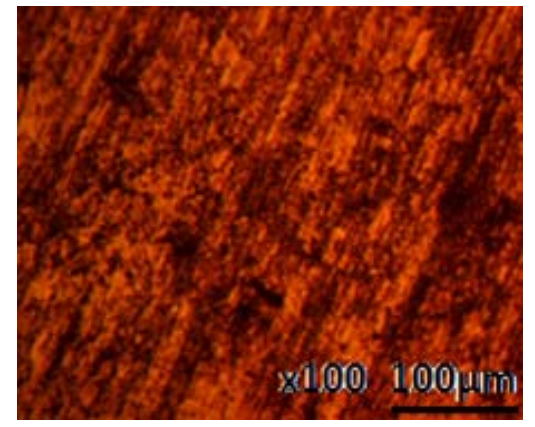

(b)

Fig. 9. Optical microscopy image of $\mathbf{S} 41003$ sample from $\mathrm{HCl}$ solution (a) corroded $\mathrm{S} 41003$, (b) ROZ inhibited S41003



(a)

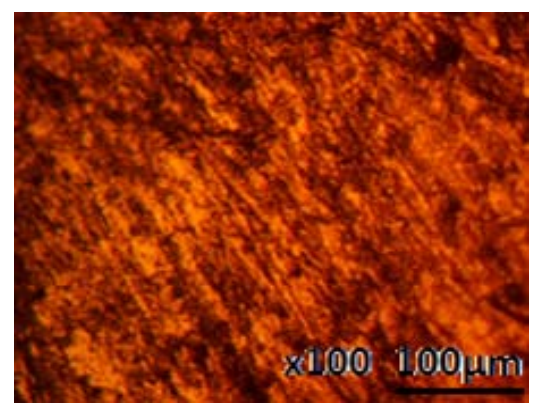

(b)

Fig. 10. Optical microscopy image of $\mathrm{S} 41003$ sample from $\mathrm{H}_{2} \mathrm{SO}_{4}$ solution (a) corroded $\mathrm{S} 41003$, (b) ROZ inhibited $\mathrm{S} 41003$

Table. 6: Analysis of variance (ANOVA) for $\mathrm{S} 41003$ in $1 \mathrm{M} \mathrm{HCl} \mathrm{\&} \mathrm{H}_{2} \mathrm{SO}_{4}$ at $95 \%$ confidence level

\begin{tabular}{|c|c|c|c|c|c|c|}
\hline \multicolumn{7}{|l|}{$\mathrm{HCl}$} \\
\hline $\begin{array}{l}\text { Source of } \\
\text { Variation }\end{array}$ & $\begin{array}{l}\text { Sum of } \\
\text { Squares }\end{array}$ & $\begin{array}{c}\text { Degree of } \\
\text { Freedom }\end{array}$ & $\begin{array}{l}\text { Mean } \\
\text { Square }\end{array}$ & $\begin{array}{c}\text { Mean Square } \\
\text { Ratio (F) }\end{array}$ & $\begin{array}{c}\text { Significance F } \\
\text { (Min. MSR at 95\% } \\
\text { confidence) }\end{array}$ & $\mathrm{F}(\%)$ \\
\hline $\begin{array}{l}\text { ROZ concentration } \\
\text { Exposure Time } \\
\text { Residual } \\
\text { Total } \\
\mathrm{H}_{2} \mathrm{SO}_{4}\end{array}$ & $\begin{array}{l}328.76 \\
-197508 \\
-27401.3 \\
-224580\end{array}$ & $\begin{array}{c}4 \\
4 \\
16 \\
24\end{array}$ & $\begin{array}{c}82.19 \\
-49376.9 \\
-1712.58\end{array}$ & $\begin{array}{l}-0.05 \\
28.83\end{array}$ & $\begin{array}{l}2.53 \\
2.42\end{array}$ & $\begin{array}{c}-0.14639 \\
87.99\end{array}$ \\
\hline $\begin{array}{l}\text { Source of } \\
\text { Variation }\end{array}$ & $\begin{array}{l}\text { Sum of } \\
\text { Squares }\end{array}$ & $\begin{array}{l}\text { Degree of } \\
\text { Freedom }\end{array}$ & $\begin{array}{l}\text { Mean } \\
\text { Square }\end{array}$ & $\begin{array}{c}\text { Mean Square } \\
\text { Ratio (F) }\end{array}$ & $\begin{array}{c}\text { Significance } F \\
\text { (Min. MSR at 95\% } \\
\text { confidence) }\end{array}$ & $F(\%)$ \\
\hline $\begin{array}{l}\text { ROZ concentration } \\
\text { Exposure Time } \\
\text { Residual } \\
\text { Total }\end{array}$ & $\begin{array}{c}299.7 \\
-189831 \\
-8067.27 \\
-197599\end{array}$ & $\begin{array}{c}4 \\
4 \\
16 \\
24\end{array}$ & $\begin{array}{c}74.92 \\
-47457.7 \\
-504.2\end{array}$ & $\begin{array}{l}-0.15 \\
94.12\end{array}$ & $\begin{array}{l}2.53 \\
2.42\end{array}$ & $\begin{array}{c}-0.15167 \\
96.07\end{array}$ \\
\hline
\end{tabular}


9(b) and 10(b). The morphology of $\$ 41003$ from $\mathrm{HCl}$ deteriorated further compared to the image from $\mathrm{H}_{2} \mathrm{SO}_{4}$ due to the smaller size of chloride ions than sulphates which enables its diffusion through the passive oxide film of $S 41003^{34}$. The mild deterioration of ROZ inhibited $\mathrm{S} 41003$ samples is probably due to pre-adsorbed anions before adsorption of ROZ cations by physisorption mechanism through Vander Waals forces onto the steel. This inhibits further diffusion and electrolytic transport of chloride and sulphates anions.

\section{Statistical analysis}

Statistical analysis through ANOVA at a confidence level of $95 \%$ (significance level of $\alpha=$ 0.05 ) was used to calculate the statistical influence of $\mathrm{ROZ}$ concentration and exposure time on $\mathrm{ROZ}$ inhibition efficiency values on $\mathrm{S} 41003$ in $\mathrm{HCl}$ and $\mathrm{H}_{2} \mathrm{SO}_{4}$ solutions according to eqns. (11-13). The Sum of squares among columns (ROZ concentration)

$S S_{\mathrm{c}}=\frac{\sum T_{\mathrm{c}}^{2}}{n r}-\frac{T^{2}}{N}$

Sum of Square s among rows (Exposure time)

$S S_{\mathrm{r}}=\frac{\sum T_{\mathrm{r}}^{2}}{n c}-\frac{T^{2}}{N}$

Total Sum of Squares

$$
S S_{\text {Total }}=\sum x^{2}-\frac{T^{2}}{N}
$$

Statistical data in Table 6 showed that exposure time is the only relevant statistical variable statistically responsible for $\mathrm{ROZ}$ inhibition efficiency values with $F$-values of 28.83 in $\mathrm{HCl}$ and 94.12 in
$\mathrm{H}_{2} \mathrm{SO}_{4}$ solution respectively. These values are greater than the control significance factor (significance $F$ ) value of 2.42 , corresponding to a percentage significance of $87.99 \%(\mathrm{HCl})$ and $96.07 \%\left(\mathrm{H}_{2} \mathrm{SO}_{4}\right)$. The results show that change in exposure time has strong influence the electrochemical corrosion behavior and inhibitor protection of ROZ on S41003 stainless steel alloy in contrast to $\mathrm{ROZ}$ concentration which is statistically irrelevant. ROZ inhibition efficiency is independent of inhibitor concentration as a result irrespective of concentration, the efficiency of ROZ compound changes with time.

\section{CONCLUSION}

The synergistic effect of rosemary oil and zinc oxide performed effectively on the corrosion inhibition $\mathrm{S} 41003$ ferritic steel in $\mathrm{HCl}$ and $\mathrm{H}_{2} \mathrm{SO}_{4}$ acid solutions from electrochemical analysis, weight loss test and corrosion potential monitoring. The admixture compound formed a protective covering over the steel through physisorption mechanism according to the Langmuir and Frumkin adsorption isotherm. Identified functional groups completely adsorbed onto $\mathrm{S} 41003$ steel in $\mathrm{H}_{2} \mathrm{SO}_{4}$ but aggregated in $\mathrm{HCl}$ forming a protective covering through surface coverage from analysis of the adsorption spectra. The optical images of the inhibited steel samples slightly contrast the images without ROZ compound due to preadsorbed sulphate and chloride anions onto the steel.

\section{ACKNOWLEDGEMENT}

The author acknowledges Covenant University Ota, Ogun State, Nigeria for the sponsorship and provision of research facilities for this project.

\section{REFERENCES}

1. Tantawy, N. The Annals of University Dunãrea de JOS of Galapi Fascicle VIII., 2005,112-114.

2. Sastri, V.S. Green Corrosion Inhibitors Theory and Practice, Wiley, Yukon, Canada., 2011.

3. Raja. P.B.; Sethuraman, M.G. Mats. Letts., 2008, 62, 113-116.

4. Obi-Egbedi, N.O.; Obot, I.B.; Umoren, S.A.
Arabian J. of Chem., 2012, 5(3), 361-373.

5. Hussin. M.H.; Kassim, M.J. Int. J. of Elect. Sci., 2011, 6(5), 1396-1414.

6. ASTM G1 - 03(2011), Standard Practice for Preparing, Cleaning, and Evaluating Corrosion Test Specimens. http://www.astm. org/Standards/G1 [Accessed: 30/05/16]. 
7. Ozcan, M.M.; Chalchat, J.C. Int. J. of Food Sciences \& Nutrition., 2008, 59(7-8), 691-698

8. ASTM G59 - 97(2014). Standard Test Method for Conducting Potentiodynamic Polarization Resistance Measurements. http:// www.astm.org/Standards/G31 [Accessed: 30/05/16].

9. ASTM G102-89(2015)e1. Standard Practice for Calculation of Corrosion Rates and Related Information from Electrochemical Measurements. http:// www.astm. org/ Standards /G31 [Accessed: 30/05/16).

10. Basics of corrosion measurements http:// www. che.sc. edu/ faculty /popov/ drbnp/ ECHE 789b/Corrosion \%20M easurements. pdf [Accessed: 06/04/17).

11. Corrosion Part 2 - Measurement of Corrosion Rates http:// www. Ecochemie .nl/ download /Applicationnotes/Autolab_ Application_Note_COR02.pdf [Accessed: 06/04/17]

12. Choi, Y.; Nesic, S.; Ling, S. Electrochim. Acta., 2011, 56, 1752-1760.

13. ASTM G31 - 72, Standard Practice for Laboratory Immersion Corrosion Testing of Metals. https://www.astm.org/database cart/ historical/G31-72R04. htm[Accessed: 06/04/ 2017]

14. Venkatesan, P.; Anand, B.; Matheswaran, P. E-J. of Chem., 2009, 6(S1), S438-S444.

15. Schutt, H.U.; Horvath, R.J. Crude Column Overhead Corrosion Problem Caused by Oxidized Sulfur Species, NACE, Houston, Texas, 1987.

16. Schofield, M.J, Plant Engineer`s Reference Book, Elsevier, 2003.

17. ASTM G69 - 12. Standard test method for measurement of corrosion potentials of aluminum alloys. https://www.astm.org/ Standards/G69.htm [Accessed: 21/05/2017].

18. Loto, R.T.; Loto, C.A. Cogent Chem., 2016, 2, 1268377. http://dx.doi.org /10. 1080 /
23312009.2016 .1268377$.

19. Stone, P.J. Corrosion Inhibitors for Oil and Gas Production, Corrosion, ASM Handbook, ASM International., 1987 13,.

20. Zaim, S.; Muralidharan, S.; Iyer, S.; Muralidharan, B.; Vasudevan, T. Br. Corros. J., 1998, 33, 297.

21. Cisse, M.B.; Zerga, B.; El Kalai, F.; Touhami, M.E.; Sfaira, M.; Taleb, M.; Hammouti, B.; Benchat, N.; El Kadiri, S.; Benjelloun, A.T. Surf. Rev. Lett., 2011, 18(6), 303-313.

22. Bockris, J.O.; Drazic, D.; Despic, A.R. Electrochim. Acta., 1961, 4(2-4), 325-361.

23. Bockris, J.O.; Kita, H. J. of the Elect. Soc., 1961, 108(7), 676-685.

24. Refaey, S.A.M.; Taha, F.; Abd El-Malak, A.M. Int. J. of Elect. Sci., 2006, 1, 80-91.

25. Limousin, G.; Gaudet, J.P.; Charlet, L.; Szenknect, S.; Barthes, V.; Krimissa, M. Appl. Geochem., 2007, 22, 249-275.

26. Allen, S.J.; Mckay, G.; Porter, J.F. J. Colloid Interface Sci., 2004, 280, 322-333.

27. Guidelli, R. Adsorption of Molecules at Metal Electrodes, Lip Kowski, J.; Ross, P.N. (eds.), VCH Publishers, Inc., Ncw York, p.1., 1992.

28. Hosseini, M.; Mertens, S.F.L.; Arshadi, M.R. Corros. Sci., 2003, 45, 1473-1489.

29. Aharoni, C.; Ungarish, M. J. Chem. Soc. Faraday Trans., 1977, 73, 456-464.

30. Loto, R.T. Rev. Colomb. Quim., 2017, 46(1), 20-32.

31. Loto, R.T.; Loto, C.A.; Popoola, A.P.I.; Fedotova, T. Arabian J. of Chem. 2015. http:/ /dx.doi.org/10.1016/j.arabjc.2014.12.024

32. Table of Characteristic IR Absorptions. http:/ /orgchem.colorado.edu/Spectroscopy/ specttutor/irchart.pdf. [Accessed: 12/01/2017].

33. George, S. Infrared and Raman Characteristic Group Frequencies: Tables and Charts, John Wiley \& Sons, New York., 2004.

34. Loto, R.T. J. Mater. Environ. Sci., 2013, 4(4), 448-459 